\title{
Ecological energy accounting for the gambling sector: A case study in Macao
}

\author{
Kampeng Lei ${ }^{a}$, Shaoqi Zhou ${ }^{a}$, Dan Hu ${ }^{\text {b,* }}$, Yingying Yu ${ }^{b}$ \\ ${ }^{a}$ College of Environmental Science and Engineering, South China University of Technology, Guangzhou, China \\ ${ }^{\mathrm{b}}$ State Key Lab of Urban E' Regional Ecology, Research Center for Eco-Environmental Sciences, Chinese Academy of Sciences, 18 Shuangqing Road, Beijing 100085, China
}

\section{A R T I C L E I N F O}

\section{Article history:}

Received 3 December 2009

Received in revised form 13 April 2010

Accepted 14 April 2010

\section{Keywords:}

Emergy

Emergy indicators

Gambling sector

Macao

\begin{abstract}
A B S T R A C T
Macao is a population-dense society that depends heavily on exogenous natural resources. In parallel with an expanding gambling sector, tourism became the most important driving force in Macao's economy. Economic growth in Macao has now benefited from the gambling boom and associated tourism for more than two decades. Although traditional economic theory has been used to deal with the economics of the gambling sector, the materials and energy foundation for this sector has not been previously analyzed. This is an important omission from the literature, since the gambling sector provides gamblers with food, tickets, services, water, electricity, equipment, labor, and other services that consume large quantities of materials and energy. In this paper, emergy synthesis is introduced to analyze Macao's gambling sector in 2004. Macao's casinos provide a dense flow of services that favor gambling tourists, since the emergy $/ \$$ ratio $\left(1.42 \times 10^{12} \mathrm{sej} / \$\right)$ for the sector is much lower than that for Macao as a whole $\left(2.38 \times 10^{12} \mathrm{sej} / \$\right)$. The emergy imports by this sector totaled $78.1 \times 10^{20} \mathrm{sej}$, and its exports were $77.1 \times 10^{20} \mathrm{sej}$. The emergy of services therefore plays an important role in Macao's gambling sector, and the transformity of an employee in this sector $\left(11.2 \times 10^{16} \mathrm{sej} /\right.$ person $)$ was much higher than that of a typical person in Macao $\left(5.27 \times 10^{16} \mathrm{sej} /\right.$ person $)$.
\end{abstract}

(c) 2010 Elsevier B.V. All rights reserved.

\section{Introduction}

In recent decades, the field of ecological economics, which integrates systems ecology with classical economics, has provided an innovative approach to understanding the interdependent relationships between the environment and man (Costanza et al., 1997). The emergy evaluation model developed by H.T. Odum has proven to be a useful tool for measuring the environment's contribution to human welfare (Ulgiati et al., 1994; Odum, 1996; Huang, 1998; Ulgiati and Brown, 1998; Brown and Ulgiati, 1999; Huang and Hsu, 2003). Emergy analysis considers all systems to be networks of energy flows, and determines the value of these streams in emergy units. "Emergy is a universal measure of real wealth of the work of nature and society made on a common basis" that allows direct comparisons between flows of money, energy, and materials despite the different units used to measure these flows (Odum and Odum, 2001; Ulgiati and Brown, 2009). The characteristics and advantages of emergy analysis method were concisely stated by Hu et al. (2009) and Li and Wang (2009).

Gambling and related tourism activities represent a special form of economic and societal activity. Since 2000, the framework of emergy analysis has been used to analyze tourism (Abel, 2000;

\footnotetext{
* Corresponding author. Tel.: +8610 62849199; fax: +86 1062849103 .

E-mail address: hudan@rcees.ac.cn (D. Hu).
}

Brown and Ulgiati, 2001). In these and other studies, emergy inflows from tourism have been accounted for in the following areas: (1) transportation, since the tourists must be brought to the study area and move around once they have arrived; (2) local services, such as those provided by the hotel industry, since these are consumed directly and indirectly to maintain and promote the industries that support tourists during their stay; (3) imported goods (including the emergy of shipping and foods), since these emergy inflows into the retail subsystem also sustain tourist activities; and (4) labor, since tourism is supported by a large labor force that embodied a substantial emergy inflow. The sum of these categories of imports represents the total emergy exports of tourism, since tourists take these benefits with them when they leave the study system, even though the exchange processes happen within the host region (Abel, 2000). Brown and Ulgiati (2001) have studied tourism resorts in Mexico and Papua New Guinea, and proposed that economic development is related to the net emergy benefits created by tourism, and that these net benefits represent a positive net trade in emergy.

Despite these previous studies, the emergy accounting method has not been used to analyze the gambling sector. In the present paper, we use emergy accounting to illustrate the emergy flows within Macao's gambling sector. To do so, we analyze the emergy flows through this sector and calculate several emergy-based indicators for the sector to let us analyze the functioning and efficiency of this sector. 


\section{An overview of Macao and its gambling sector}

Macao had a population of 465333 in 2005. This special administrative region lies between the longitudes of $111^{\circ} 31^{\prime} 33^{\prime \prime} \mathrm{E}$ and $111^{\circ} 35^{\prime} 43^{\prime \prime} \mathrm{E}$ and the latitudes of $22^{\circ} 06^{\prime} 39^{\prime \prime} \mathrm{N}$ and $22^{\circ} 13^{\prime} 06^{\prime \prime} \mathrm{N}$, at the western side of the Pearl River estuary. Macao's annual temperature averages $22.3^{\circ} \mathrm{C}$ (The Maritime Administration, 2005) due to its location within the southern edge of the northern tropics. The region covered $27.5 \mathrm{~km}^{2}$ in 2004 , including the Macao Peninsula, Taipa Island, Coloane Island, and the Cotai Reclaimed Land.

Macao's gambling sector can be traced back to the 16th century, when Macao first opened its harbor to visitors (McCartney, 2005). After Hong Kong's sovereignty was ceded to the British in 1842, Macao's was gradually replaced as an important trading port by Hong Kong. In an effort to fill its depleted coffers and diversify its economic activities, Macao's Portuguese government legalized gambling for the first time in 1847. At the time, Macao was renowned as "the Monte Carlo of the Orient".

In 2002, Macao's government ended its monopoly on gambling and granted three (later six) casino operating concessions and subconcessions to six local and international gambling companies. In May 2004, the first casino of Venetian, Casino Sands, was opened. It was the first ever gaming investment project developed by an American company in Asia. In the same year, Galaxy's first project (Casino Waldo) also commenced operations. By the end of 2004, 17 casinos were operating in Macao (The Statistics and Census Service, 2005).

Gambling plays an important role in Macao's economy (Table 1). The gambling activities can be divided into three main categories: casino games, horse racing, and greyhound racing (Table 2). In addition, sports betting and a number of lotteries are available, and provide a significant contribution to the economy. The casino industry, which accounts for about $95 \%$ of gambling revenues, is viewed by many as harmful to society because of its high social and economic costs for gamblers who come from nearby regions. A high crime rate that resulted from these economic conditions was one of the biggest problems faced by Macao's society. Since Macao's return to Chinese rule in 1999, the public security situation has markedly improved (Lei and Wang, 2008a).

Table 1

Number of gaming tables, slot machines, and pachinko machines from 2002 to 2004.

\begin{tabular}{lllr}
\hline Types & 2002 & 2003 & 2004 \\
\hline Gaming tables & 339 & 424 & 1092 \\
Slot machines & 808 & 814 & 2254 \\
Pachinko machines & 188 & 188 & 188 \\
\hline
\end{tabular}

Source: The Gaming Inspection and Coordination Bureau of Macao (2006).

Table 2

Gross revenues from Macao's main gambling activities from 2002 to 2004.

\begin{tabular}{lccc}
\hline & \multicolumn{3}{c}{ Revenues $\left(\times 10^{7}\right.$ US $\left.\$\right)$} \\
\cline { 2 - 4 } Items & 2002 & 2003 & 2004 \\
\hline Games of chance & 268.22 & 347.18 & 521.74 \\
Greyhound racing & 0.95 & 0.92 & 1.09 \\
Horse racing & 6.71 & 12.50 & 20.33 \\
Chinese lotteries & 0.05 & 0.04 & 0.06 \\
Instant lotteries & 0.01 & 0.001 & 0.001 \\
Sports lotteries - football (soccer) & 7.74 & 6.18 & 5.57 \\
Sports lotteries - basketball & 0.67 & 0.62 & 0.45 \\
Total & 284.35 & 367.47 & 549.25 \\
\hline
\end{tabular}

Source: The Gaming Inspection and Coordination Bureau of Macao (2006).
Gambling remains a pillar of Macao's economic. Information from The Statistics and Census Service (2005) indicates that real GDP reached $\$ 10.31$ billion in 2004 (all values in U.S. dollars). In 2004 , gambling taxes generated an estimated $78.8 \%$ of the Macao Special Administrative Region's total fiscal revenues (The Gaming Inspection and Coordination Bureau of Macao, 2006). The success of Macao's gambling sector is primarily due to its official support by the government, robust investments by entrepreneurs, and the gambling preferences of Asians.

\section{Study methodology}

We used the conventional emergy synthesis method of Odum (1996) to study the flows of materials, energy, and money using a single metric. To account for the emergy of labor, we have proposed a quantitative method that is introduced in Section 3.2. Unless otherwise indicated, all data used in the present analysis were provided by Macao's Statistics and Census Service (2005).

\subsection{Emergy analysis}

Emergy is defined as all the available energy that has been used to make a product, including both direct and indirect forms of energy. Transformity represents the amount of one type of emergy that is required to create a unit of energy of another type. An important concept in emergy analysis is the solar transformity, which is defined as the amount of solar emergy (in solar emjoules, sej) required to create $1 \mathrm{~J}$ of a service or product (Odum, 1996). Solar transformity, which represents the equivalent solar energy embodied in a given service or product, is measured in sej/J. The solar transformity of a product $(\tau)$ is its solar emergy $\left(E_{\mathrm{m}}\right)$ divided by its available energy $(E)$ :

$\tau=\frac{E_{\mathrm{m}}}{E}$

Since solar energy is the baseline for all emergy calculations, the transformity of solar energy is considered to equal 1. The emergy of economic imports measured in monetary terms is determined by multiplying the imports in monetary units $(C)$ by the ratio of a study region's total emergy to its economic gross domestic product (emergy/\$).

$E_{\mathrm{m}}=C\left(\frac{\text { emergy }}{\$}\right)$

In contrast, a region's emergy value is divided by the emergy $/ \$$ ratio to determine the equivalent emdollars.

\subsection{Emergy analysis of the gambling sector}

To analyze the emergy consumption by the many visitors to Macao, we have adopted a computational approach based on Eqs. (1) and (2), plus additional equations developed in this section. The buying power of money (Odum, 1996) imported by visitors $\left(T_{\mathrm{m}}\right)$ differs from the monetary value consumed by visitors ("service exports", abbreviated as $M_{\mathrm{t}}$ ) and flows in the opposite direction. Since the services of a tourism city such as Macao are shared by local residents and visitors, we used a proportional approach (Eqs. (1) and (2)) to calculate the service exports and emergy consumption by visitors (Lei et al., 2006; Lei and Wang, 2008a,b):

$R_{\mathrm{t}}=\frac{T d r}{T d r+365 P}$

where $R_{\mathrm{t}}$ is the ratio of visitor-consumed emergy to total emergy use $(U), T$ is the number of tourists, $d$ is the average duration of their stay (days), $P$ is the population of Macao, and $r$ is the consumption 
factor per visitor, which represents the ratio of consumption by tourists to consumption by residents. In 2004, we chose $r=1.9$ for calculations (Lei and Wang, 2008a), which means that tourists consumed roughly twice as many resources as a local citizen (Lei and Wang, 2008b). The service exports by tourists are defined as:

$M_{\mathrm{t}}=U R_{\mathrm{t}}$

The emergy of labor was measured by multiplying the population of employees $(W)$ in the gambling sector by the ratio of the city's total emergy to its total number of employees (the per capita $\left.E_{\mathrm{m}}\right)$.

$E_{\mathrm{m}}=W \times$ per capita $E_{\mathrm{m}}$

We have also used the following emergy-based indicators in our analysis (Lei and Wang, 2008a) of Macao's gambling sector:

- Renewable resource $(R)$ : the emergy inputs from environmental sources.

- Imports $(F)$ : the flow of emergy imported in the form of goods and services from outside the region, including fuels, minerals, raw materials, goods, and imported services.

- Exports $(Y)$ : the flow of emergy exported in the form of goods and services to the outside market.

- Emergy exchange ratio (EER): the ratio of emergy exchanged in a trade or purchase (i.e., the ratio of emergy received to emergy given).

- Emergy yield ratio (EYR): the ratio of the emergy yield from a process to the emergy imports $(Y / F)$.

- Net emergy: the surplus emergy or emergy deficit of the system or region as a result of the exchange process and the nonrenewable emergy exploited during the year under investigation, where net emergy $=R+F-Y$.

- Net emergy ratio $(N E R)$ : the ratio of net emergy to the total emergy used $(U)$.

\section{Results and discussion}

The case study in this paper used data from 2002 to 2004 , a period in which Macao's gambling and tourism industry grew rapidly. The data were provided by The Statistics and Census Service (2005) and The Gaming Inspection and Coordination Bureau of Macao (2006). The emergy data were obtained from our calculations and from previously published results (Lei and Wang, 2008b). We adopted the $9.26 \times 10^{24}$ sej planetary baseline for annual emergy imports (Campbell et al., 2004). The results of our calculations appear in Table 3 (emergy flows) and Table 4 (emergy indicators). Fig. 1 summarizes Macao's emergy flows through Macao's gambling sector. The imports $(F)$ represent purchased resources (food, water, electricity, equipment rent, and materials), labor, and operating services. The exports $(Y)$ represent the profit of the casinos companies and the government taxes. Renewable resources emergy ( $R$, including sunlight, wind, and beautiful sights) and nonrenewable resources emergy ( $N$, including sand, stone, winds and other materials in casinos) were also consumed by the gambling sector, but because it was not possible to find data on these emergies specifically for this economic sector, we assumed that the total emergy used $(U)$ equaled the imports $(F)$ by the gambling sector, and we have omitted data on these specific emergy data from Fig. 1. The services and recreation emergy consumed by gambling are consumed by gamblers during the betting process.

Macao is a tourism-dominated city, with a huge number of tourists arriving every day; the emergy consumed by the gambling sector accounted for about $36.3 \%$ of the city's total emergy use in 2004 (Table 4). Table 4 shows that the EER (emergy exchange ratio) of tourism of Macao increased from 1.16 in 1983 to 3.16 in 2004 (Table 4). A high ratio means that the system captures more emergy wealth through the services it provides to tourists. Table 5 summarizes the emergy synthesis for food and beverage imports and consumption in Macao's gambling sector in 2004. Table 6 summarizes the emergy imports and exports for Macao's gambling sector in 2004. These results will be discussed in more detail in the remainder of this section.

To analyze the emergy of the gambling sector, we must be able to estimate the quantity of gamblers per year, but there were no officially available data for this specific statistic. The population of gamblers was instead provided by the Sociedade de Jogos de Macau (2006, personal communication), which operated 15 of the total 17 of casinos in Macao in 2004. Based on this data, $70 \%$ of the visitors participate in the gambling sector $(70 \% \times 16673000=11671100)$; of these people, about $90 \%$ are from overseas, and the remaining $10 \%$ are local residents (1 296788 ). So in 2004, the number of gamblers was about $(70 \% \times 16673000) / 90 \%=12967888$. We used this quantity for our analysis of the emergy consumption by the gambling sector in the following sections (Fig. 2).

\subsection{Water emergy}

Water is an important resource in the gambling sector. It is used for spraying (e.g., in fountains), cleaning, toilet flushing, restaurants, hotels, drinks, and other uses. In 2004, the water cost was $1.154 \times 10^{6}$ US\$ (The Gaming Inspection and Coordination Bureau of Macao, 2006). At a price of $0.547 \mathrm{US} \$ / \mathrm{m}^{3}$, we used an estimated water consumption (based on the purchase data) of $2.11 \times 10^{6} \mathrm{~m}^{3}$, which is equivalent to an emergy of $1.04 \times 10^{13} \mathrm{~J}$ (The Gaming Inspection and Coordination Bureau of Macao, 2006).

The emergy of the used water $=2.11 \times 10^{6} \mathrm{~m}^{3} \times 1 \mathrm{t} / \mathrm{m}^{3} \times$ $1000000 \mathrm{~g} / \mathrm{t} \times 4.94 \mathrm{~J} / \mathrm{g} \times 660000 \mathrm{sej} / \mathrm{J}=0.688 \times 10^{19} \mathrm{sej}$.

Table 3

Summary of emergy flows for Macao in 2004 (Lei and Wang, 2008b).

\begin{tabular}{|c|c|c|c|c|}
\hline Variable & Item & Energy $(\mathrm{J})$ or mass $(\mathrm{g})$ & Solar emergy $\left(\times 10^{20} \mathrm{sej}\right)$ & Emdollars $\left(\times 10^{9} \mathrm{em} \$\right)$ \\
\hline$R$ & Renewable resources & $1.11 \times 10^{15}$ & 0.27 & 0.01 \\
\hline$N$ & Nonrenewable resources & $3.62 \times 10^{11}$ & 3.60 & 0.15 \\
\hline Fuel & Imported fuels and minerals & $3.16 \times 10^{16}$ & 30.14 & 1.28 \\
\hline$G$ & Imported foods, goods, and raw materials & $7.03 \times 10^{15}$ & 187.50 & 7.86 \\
\hline$P 2 I$ & Emergy of services from outside the study area & $1.43 \times 10^{9}$ & 23.77 & 1.00 \\
\hline Imports $(F)$ & Imported emergy: Fuel $+G+P 2 I$ & $3.86 \times 10^{16}$ & 241.34 & 10.14 \\
\hline$U$ & Emergy used: $R+N+F$ & $3.97 \times 10^{16}$ & 245.21 & 10.31 \\
\hline$B$ & Exported production & $3.00 \times 10^{15}$ & 136.29 & 5.73 \\
\hline$M_{\mathrm{t}}$ & Tourist consumption & & 41.75 & 1.75 \\
\hline Exports $(Y)$ & Exported emergy $\left(B+M_{\mathrm{t}}\right)$ & & 178.04 & 7.48 \\
\hline$E L E$ & Electricity: $1880 \mathrm{GWh}$ & $7.36 \times 10^{15}$ & 11.68 & 0.61 \\
\hline GDP & Gross domestic product (US\$) & $1.03 \times 10^{10}$ & - & - \\
\hline$P 2$ & World emergy $/ \$$ ratio & $1.66 \times 10^{12}$ & - & - \\
\hline$P 1$ & Macao’s emergy/\$ ratio & $2.38 \times 10^{12}$ & - & - \\
\hline
\end{tabular}


Table 4

Emergy and tourism-related indicators for Macao from 1983 to $2004^{\mathrm{a}}$.

\begin{tabular}{|c|c|c|c|c|}
\hline Indicators & 1983 & 1993 & 2003 & 2004 \\
\hline Population & 282843 & 383984 & 448495 & 465333 \\
\hline GDP $\left(\times 10^{9}\right.$ US\$ $)$ & 1.15 & 5.67 & 7.90 & 10.31 \\
\hline Tourists per year $\left(\times 10^{3}\right)$ & 4101 & 5998 & 11888 & 16673 \\
\hline Tourists/population & 14.5 & 15.6 & 26.5 & 35.8 \\
\hline Tourism income $\left(\times 10^{9}\right.$ US $\left.\$\right)$ & 0.50 & 2.48 & 5.21 & 8.10 \\
\hline Gambling income $\left(\times 10^{9}\right.$ US\$) & 0.21 & 1.77 & 3.58 & 5.49 \\
\hline$T_{\mathrm{m}}\left(\times 10^{20} \text { sej }\right)^{\mathrm{b}}$ & 11.05 & 49.09 & 86.50 & 134.56 \\
\hline$M_{\mathrm{t}}\left(\times 10^{20} \mathrm{sej}\right)^{\mathrm{c}}$ & 9.56 & 25.24 & 32.54 & 42.60 \\
\hline Emergy $/ \$$ of Macao $\left(\times 10^{12} \mathrm{sej} / \$\right)$ & 8.76 & 4.36 & 2.78 & 2.38 \\
\hline Emergy used $\left(U, \times 10^{20} \mathrm{sej}\right)$ & 100.45 & 247.02 & 219.73 & 245.21 \\
\hline Gambling income ${ }^{\mathrm{d}}\left(\times 10^{20} \mathrm{sej}\right)$ & 4.61 & 35.00 & 59.40 & 91.24 \\
\hline Emergy exchange ratio (EER) of tourism ${ }^{\mathrm{e}}\left(T_{\mathrm{m}} / M_{\mathrm{t}}\right)$ & 1.16 & 1.83 & 2.65 & 3.16 \\
\hline Tourism net emergy $\left(T_{\mathrm{m}}-M_{\mathrm{t}}\right)$ & 1.54 & 22.22 & 53.92 & 91.96 \\
\hline Net emergy ratio (NER) of tourism ${ }^{\mathrm{e}}$ & 0.14 & 0.45 & 0.62 & 0.68 \\
\hline$T_{\mathrm{m}} / \mathrm{GDP}(\%$, US\$ basis) & 44.0 & 43.7 & 65.9 & 78.6 \\
\hline Gambling taxes (\% of government revenues) & 38.0 & 46.2 & 74.9 & 78.8 \\
\hline Gambling/GDP (\%, US\$ basis) & 18.3 & 31.1 & 45.3 & 53.2 \\
\hline Gambling/U (\%, sej basis) & 4.6 & 13.3 & 27.0 & 37.2 \\
\hline
\end{tabular}

a The population, GDP, tourist numbers, and tourism income were provided by The Statistics and Census Service (2005).

b $T_{\mathrm{m}}$ is the emergy of tourism income, and was obtained from Lei et al. (2008).

c $M_{\mathrm{t}}$ was obtained from Lei and Wang (2008a).

d Gambling income was converted from monetary to emergy terms using Eq. (2).

e EER of Tourism, tourism net emergy, and the net emergy ratio of tourism were obtained from Lei and Wang (2008a).

By dividing this emergy by the number gamblers in 2004 $\left(12.97 \times 10^{6}\right)$, the average water emergy consumption per tourist would be $0.53 \times 10^{12}$ sej.

\subsection{Electricity emergy}

Electricity is an important resource in the gambling sector. It powers the air conditioning, lights the casinos, and runs the slot machines and other equipment, as well as the hotel machinery and other equipment required to support tourism. In 2004, the gambling sector paid for $2.14 \times 10^{7}$ US $\$$ of electricity at an average price of $0.13834 \mathrm{US} \$ / \mathrm{kWh}$.
The emergy of the used electricity $=\left(2.14 \times 10^{7} / 0.13834\right) \times$ $1000 \times 3600 \mathrm{~J} \times 160000 \mathrm{sej} / \mathrm{J}=8.91 \times 10^{19}$ sej.

By dividing this quantity by the number of gamblers in 2004 $\left(12.97 \times 10^{6}\right)$, the average electricity emergy consumption per tourist would be $6.87 \times 10^{12}$ sej.

\subsection{Food and beverage emergy}

The gambling sector provides visitors with food and beverages. The sector's spending on these materials in casinos in 2004 totaled $1.77 \times 10^{8}$ US\$, with a total materials weight of about $1.47 \times 10^{8} \mathrm{~kg}$ (Table 5). After consulting the managers of these

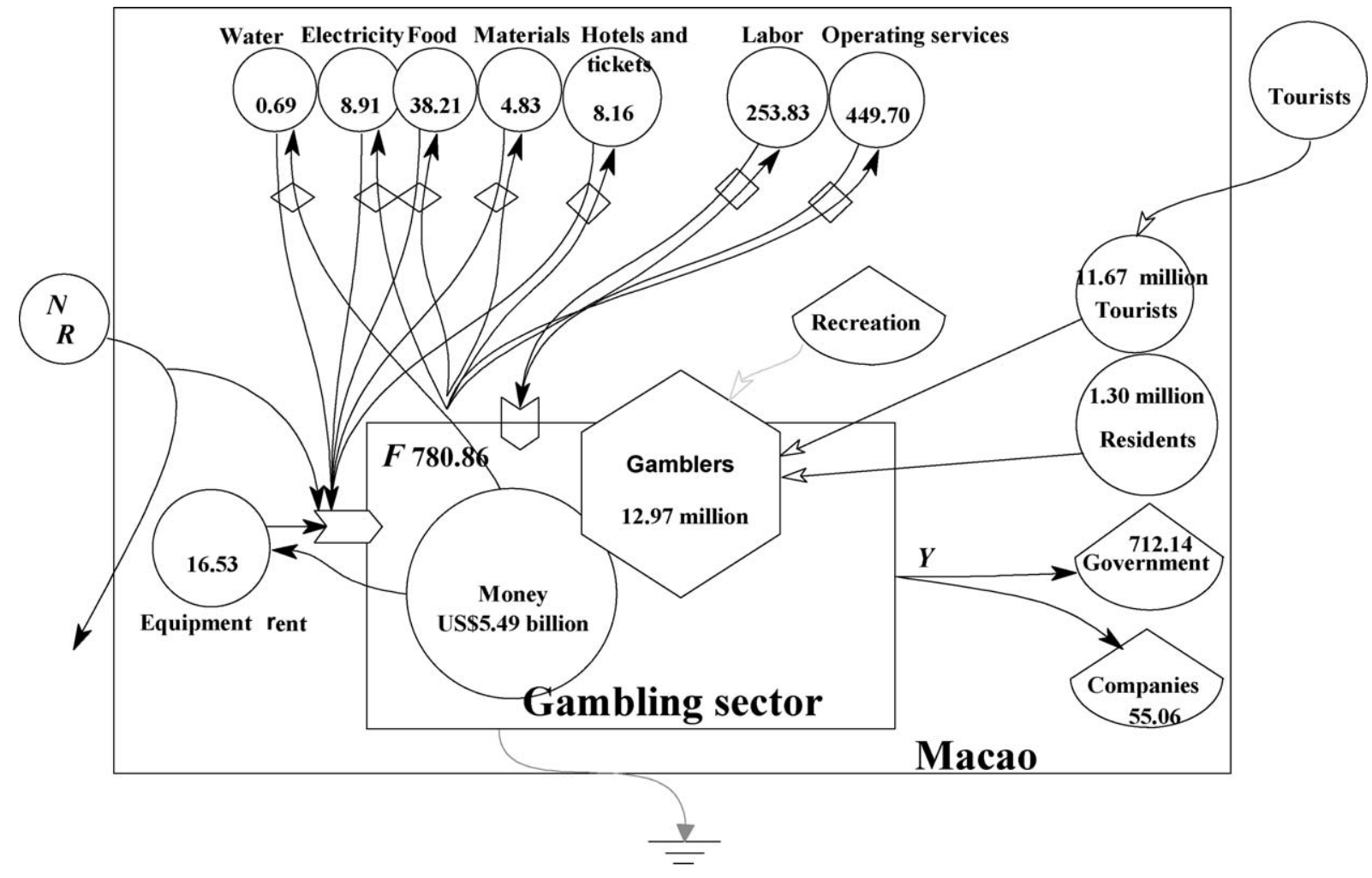

Fig. 1. A summary of the emergy flows through Macao's gambling sector. All emergy values are $\times 10^{19} \mathrm{sej} / \mathrm{year}$. 
Table 5

Food and beverage imports and consumption in Macao's gambling sector in 2004.

\begin{tabular}{|c|c|c|c|c|}
\hline Categories & Weight $\left(\times 10^{8} \mathrm{~kg}\right)$ & Spending $\left(\times 10^{8}\right.$ US\$) & Total emergy $\left(\times 10^{20}\right.$ sej $)$ & Emergy per $\mathrm{kg}\left(\times 10^{12} \mathrm{sej} / \mathrm{kg}\right)$ \\
\hline Imported food $^{\mathrm{a}}$ & 3.36 & 4.03 & 39.21 & 11.66 \\
\hline Imported beverages $^{a}$ & 0.93 & 1.24 & 0.30 & 0.33 \\
\hline Food and beverages in casinos ${ }^{\mathrm{b}}$ & 1.47 & 1.77 & 3.82 & - \\
\hline Food in casinos ${ }^{\mathrm{c}}$ & 0.29 & - & 3.44 & - \\
\hline Beverages in casinos ${ }^{c}$ & 1.18 & - & 0.38 & - \\
\hline
\end{tabular}

${ }^{a}$ The imported food and beverages represent totals from the data provided by The Statistics and Census Service (2005).

b Source: The Gaming Inspection and Coordination Bureau of Macao (2006).

c The calculation processes are discussed in Section 4.3.

Table 6

Summary of the emergy flows in Macao's gambling sector in 2004.

\begin{tabular}{|c|c|c|c|c|}
\hline Categories/items & Energy $\left(\times 10^{13} \mathrm{~J}\right)$ & Money $\left(\times 10^{8}\right.$ US\$) & Transformity (sej/Unit) & Emergy $\left(\times 10^{19}\right.$ sej $)$ \\
\hline Imports $^{\mathrm{a}}(F)$ & & & & 780.86 \\
\hline Water & 1.04 & & $6.60 \times 10^{5}$ & 0.69 \\
\hline Electricity & 55.70 & & $1.60 \times 10^{5}$ & 8.91 \\
\hline Food & & 1.77 & & 38.21 \\
\hline Equipment rent & & 0.69 & $2.38 \times 10^{12}$ & 16.53 \\
\hline Materials & & 0.29 & $1.66 \times 10^{12}$ & 4.83 \\
\hline Hotel and tickets & & 0.34 & $2.38 \times 10^{12}$ & 8.16 \\
\hline Labor & 22567 casino employees & & $1.12 \times 10^{17}$ & 253.83 \\
\hline Operating services & & 18.90 & $2.38 \times 10^{12}$ & 449.70 \\
\hline Exports $(Y)$ & & & & 767.20 \\
\hline Company profits & & 3.87 & $1.42 \times 10^{12}$ & 55.06 \\
\hline Government taxes & & 50.09 & $1.42 \times 10^{12}$ & 712.14 \\
\hline \multicolumn{5}{|l|}{ Income } \\
\hline Gambling and other receipts & & 54.93 & $1.66 \times 10^{12}$ & 912.37 \\
\hline \multicolumn{5}{|l|}{ P3 } \\
\hline Em/\$ of gambling sector & Imports/income & & $1.42 \times 10^{12}$ & \\
\hline Gamblers & & & & $12.97 \times 10^{6}$ \\
\hline
\end{tabular}

a In Macao's gambling sector, we assumed that the total emergy used $(U)$ equaled the imports $(F)$.

businesses, we estimated that $80 \%$ by weight of the total was beverages and $20 \%$ was foods.

To calculate the emergy of these foods and beverages, we used the average emergy per $\mathrm{kg}$ of Macao's foods and beverages separately.Food consumption:

Value $=20 \% \times$ food and beverages in casinos $\times$ emergy per $\mathrm{kg}$ food

$$
\begin{aligned}
& =20 \% \times 1.47 \times 10^{8} \mathrm{~kg} \times 11.66 \times 10^{12} \mathrm{sej} / \mathrm{kg} \\
& =34.36 \times 10^{19} \mathrm{sej}
\end{aligned}
$$

Beverage consumption:

Value $=80 \% \times$ food and beverages in casinos $\times$ emergy per $\mathrm{kg}$ beverages

$$
\begin{aligned}
& =80 \% \times 1.47 \times 10^{8} \mathrm{~kg} \times 0.33 \times 10^{12} \mathrm{sej} / \mathrm{kg} \\
& =3.85 \times 10^{19} \mathrm{sej}
\end{aligned}
$$

Thus, the emergy of food and beverages consumed in casinos $=34.36 \times 10^{19} \mathrm{sej}+3.85 \times 10^{19} \mathrm{sej}=38.21 \times 10^{19} \mathrm{sej}$.

By dividing this quantity by the number of gamblers in 2004 $\left(12.97 \times 10^{6}\right)$, the average emergy of food and beverages consumption per tourist would be $29.47 \times 10^{12}$ sej.

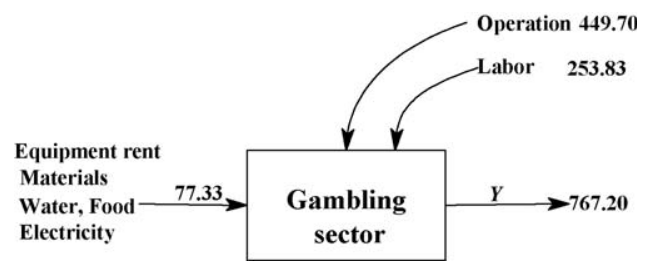

Fig. 2. Overall emergy summary diagram for Macao. All emergy values are $\times 10^{19} \mathrm{sej} / \mathrm{year}$

\subsection{Labor emergy}

The total employed population of Macao was 218013 in 2004; of these workers, 22567 worked in the gambling sector (The Statistics and Census Service, 2005). According to Eq. (5) (Table 6):Transformity per employee =emergy used/employees $=2.45 \times 10^{22} / 218013=11.2 \times 10^{16} \mathrm{sej} /$ worker.

Labor emergy in the gambling sector $=22567 \times 11.2 \times 10^{16}=$ $253.83 \times 10^{19}$ sej.

By dividing this quantity by the number of gamblers in 2004 $\left(12.97 \times 10^{6}\right)$, the average emergy labor service per tourist would be $195.73 \times 10^{12}$ sej.

The method used to evaluate the human contribution to emergy flows has been one of the major differences among emergy analysts. Some omit the labor category to avoid the question of how to evaluate this service on the same basis as the other imports (Odum, 1996). Others report the hours of labor without assigning an energy or emergy value (Lan et al., 2002). Still others calculate the energy of a person's daily metabolism, which produces a relatively small value. Ulgiati et al. (1994) evaluated the emergy consumption by labor in industrial production based on two main assumptions: untrained labor and accounting for all emergy required to support this labor. Based on this approach, Ulgiati et al. (1994) calculated the transformity for labor as $2.20 \times 10^{16} \mathrm{sej} /$ worker in Italy. In Macao, the equivalent per-worker emergy calculated using this method was $11.2 \times 10^{16}$ sej in 2004 , which was 5.1 times Italy's value in 1994. Thus, the emergy efficiency was much higher than that of Italy, although the time periods, industries, and other assumptions differ between these analyses. 
Table 7

Summary of the emergy flows in Macao and in its tourism and gambling sectors in 2004 .

\begin{tabular}{|c|c|c|c|c|}
\hline Index & Expression & Macao & Gambling sector & Tourism \\
\hline Imports (sej) & $F$ & $2.41 \times 10^{22}$ & $780.86 \times 10^{19}$ & $1.35 \times 10^{22}$ \\
\hline Emergy used (sej) & $U$ & $2.45 \times 10^{22}$ & $780.86 \times 10^{19}$ & $1.35 \times 10^{22}$ \\
\hline Exports (sej) & Y & $1.78 \times 10^{22}$ & $767.20 \times 10^{19}$ & $0.426 \times 10^{22}$ \\
\hline Emergy yield ratio (EYR) & $Y / F$ & 0.738 & 0.987 & 0.32 \\
\hline Proportion of imported services & Imported service $/ U$ & 0.097 & 0.901 & \\
\hline Emergy use per person & $U /$ population & $5.27 \times 10^{16}$ & $6.02 \times 10^{14}$ & $8.14 \times 10^{14}$ \\
\hline Emergy $/ \$$ ratio, $P 1$ (sej $/ \$$ ) & $U / G D P$ & $2.38 \times 10^{12}$ & $1.42 \times 10^{12}$ & \\
\hline Ratio of electricity to emergy use & Electricity/U & 0.059 & 0.011 & \\
\hline Average electricity per capita & Electricity $/ P$ & $3.12 \times 10^{15}$ & $6.87 \times 10^{12}$ & \\
\hline Net emergy (sej) & $R+F-Y$ & $6.36 \times 10^{21}$ & $13.66 \times 10^{19}$ & $9.20 \times 10^{21}$ \\
\hline Net emergy ratio (NER) & Net emergy/U & 0.259 & 0.018 & 0.683 \\
\hline
\end{tabular}

\subsection{Emergy/\$ ratio}

Gamblers bring money into gambling establishments for recreation as they attempt to win money. These establishments provide gamblers with food, tickets, services, water, electricity, equipment, labor, and other operating services. The gamblers gain pleasure and recreation from their activities, while mostly losing their money. The balance of imports of emergy in the form of money and exports of emergy in the form of services is summarized in Table 6.

Based on the principle of conservation of energy that is assumed by the conventional method of emergy accounting, the emergy used in the casino equals the total emergy imports. In 2004, the emergy $/ \$$ ratio for the gambling sector was $1.42 \times 10^{12} \mathrm{sej} / \$$ (Table 7), which was lower than that of Macao as a whole $\left(2.38 \times 10^{12} \mathrm{sej} / \$\right.$; Lei and Wang, 2008b).

\subsection{Emergy yield ratio}

The emergy yield ratio (EYR) represents the emergy of the exports divided by the emergy of the imports required to produce those exports (Ulgiati et al., 1994). This ratio indicates whether a process can serve as a primary emergy source for an economy. The ratio for competitive sources of fuels has typical been assumed to be greater than 1 (Odum, 1988). But for a system, a lower ratio means more net emergy transferred into the city (Lei et al., 2008). The imports emergy of Macao's gambling sector equals the total imports by casinos and other gambling establishments, whereas the exports $(Y)$ emergy equals the government revenues and profits from this sector. Table 7 shows that the EYR value for gambling sector in 2004 equals:

$E Y R=\frac{7.71 \times 10^{21}}{7.81 \times 10^{21}}=0.987$

This value was higher than the EYR for Macao as a whole (0.74) due to the large amount of profits that were taxed by the government and called "franchise revenues", it was much higher than the EYR of tourism as a whole $\left(0.32=\right.$ exports/imports $\left.=M_{\mathrm{t}}\right)$ $\left.T_{\mathrm{m}}=42.6 \times 10^{20} / 134.56 \times 10^{20}\right)$. Macao's tourism sector therefore gets net emergy that supports the region's society and other industries.

\subsection{Emergy used per gambler}

The emergy used per gambler can be obtained by dividing the imports emergy (Table 6 ) by the number of gamblers:

$\frac{\text { Imports }}{\text { Gamblers }}=\frac{780.86 \times 10^{19}}{12.97 \times 10^{6}}=6.02 \times 10^{14} \mathrm{sej} /$ gambler

This value equaled only $1.15 \%$ of the value for a Macao resident (Table 7), and equaled $74.0 \%$ of that for a tourist $\left(6.02 \times 10^{14} \mathrm{sej} /\right.$ tourist). That means that gamblers only received a small part of the services compared with the amounts received by residents and tourists when the gamblers stayed in casinos and consumed there.

\subsection{The per capita electricity emergy}

The electricity emergy per capita expresses the level of consumption of energy resources, and thus, reflects the environmental pressure created by this consumption. The electricity emergy per gambler was $6.87 \times 10^{12}$ sej (Table 7 ), which was much less than that of Macao $\left(3.12 \times 10^{15} \mathrm{sej}\right)$. The ratio of the electricity emergy to total emergy used by the gambling sector was only $1.14 \%$ (Table 7 ), which was much lower than that of Macao as a whole $(5.91 \%)$.

\subsection{The ratio of imported services to emergy used}

In the gambling sector, the dense concentrations of labor and services focus on the gambler's activities (Table 7):

Imported services $=$ operating services + labor

$$
\begin{aligned}
& =449.7 \times 10^{19} \text { sej }+253.83 \times 10^{19} \text { sej } \\
& =703.53 \times 10^{19} \text { sej }
\end{aligned}
$$

The ratio of imported services to emergy used $(U=$ imports $=$ $\left.780.86 \times 10^{19}\right)$ is high $(0.901$, versus about 0.097 for Macao as a whole). Gambling requires substantial labor and services. The newly opened casinos absorbed a large number of employees, resulting in a labor shortage for other sectors. In the near future, the gambling sector will continue to compete with other industries for the limited supply of local labor.

\subsection{Net emergy and net emergy ratio}

The net emergy of the gambling sector (i.e., $R+I-Y$ ) was $13.66 \times 10^{19}$ sej (Table 7), and its net emergy ratio = net emergy/ $U=\left(13.66 \times 10^{19}\right) /\left(780.86 \times 10^{19}\right)=0.018$.

In 2004, the net emergy ratio for the gambling sector was much lower than that of Macao (0.26) and of tourism (0.68). Most of the net emergy wealth received in gambling was transferred to the government in the form of taxes to sustain the region's society; evidently, this outflow of emergy decreased the net emergy of the gambling sector.

\subsection{Emergy exchange ratio}

The emergy exchange ratio (EER) is always expressed relative to one or the other trading partners to indicate the relative trade advantage of one partner over the other. According to Odum (1996), an EER value greater than 1 means that the received emergy exceeds the emergy that is given away during the 
Table 8

Summary of the emergy exchange ratio (EER) of Macao and of its tourism and gambling sectors.

\begin{tabular}{lrrr}
\hline Item $^{\mathrm{a}}$ & \multicolumn{1}{c}{ Received $(\mathrm{sej})$} & \multicolumn{1}{c}{ Given $(\mathrm{sej})$} & \multicolumn{1}{c}{ EER } \\
\hline Macao & $2.41 \times 10^{22}$ & $1.78 \times 10^{22}$ & 1.36 \\
Tourism & $13.46 \times 10^{21}\left(T_{\mathrm{m}}\right)$ & $4.17 \times 10^{21}\left(M_{\mathrm{t}}\right)$ & 3.16 \\
Tourists & $4.17 \times 10^{21}\left(M_{\mathrm{t}}\right)$ & $13.46 \times 10^{21}\left(T_{\mathrm{m}}\right)$ & 0.32 \\
Gambling sector & $912.37 \times 10^{19}$ & $780.86 \times 10^{19}$ & 1.17 \\
Gamblers & $780.86 \times 10^{19}$ & $912.37 \times 10^{19}$ & 0.86 \\
\hline
\end{tabular}

a Emergy flows of Macao and its tourism were obtained from Lei and Wang (2008a) and Lei et al. (2008).

exchange process. Many technologically and financially developed countries have emergy imports that are much higher than their emergy exports; for example, Italy had an EER of around 2.5 in 1994 (Ulgiati et al., 1994).

Table 8 summarizes the EER values for Macao in 2004. The EER of the gambling sector was 1.17; as a result, the gambling sector received more emergy than the exports of emergy. The EER value was less than that of Macao as a whole (1.36). On the other hand, the EER of gamblers was only 0.86 , and although this was higher than that of the tourists (0.32), an EER value less than 1 indicates that the gamblers and tourists are contributing their emergy to the gambling sector when they lose money in a casino or spend money on other tourist activities.

\section{Conclusions}

Traditionally, the emergy of labor has been obtained by multiplying the payments to workers (salaries) by a region's emergy/\$ ratio (Odum, 1996). Because gambling activities include special recreation values that are attractive to gamblers, the conventional calculation method (Eq. (2)) undervalues the relative emergy involved. Here, we developed a new equation using the transformity per person (employee) to provide a more reasonable value for the emergy of the services consumed by gambling activities. In Macao the transformity of an employee $\left(11.2 \times 10^{16} \mathrm{sej} /\right.$ person $)$ was higher than that of a worker in Italy $\left(2.20 \times 10^{16} \mathrm{sej} /\right.$ person $)$ in 2004 .

Our results also reveal the differences between gambling and other economic activities. In the gambling sector, the proportion of imported service emergy is higher (0.901) than that of Macao as a whole (0.097), but the net emergy ratio (NER) is lower (0.018) than that of Macao as a whole (0.259) because government taxation of this sector is too high. The majority of the earned emergy is exported as taxes, and these exports become an inflow for the government.

In the gambling sector, emergy exchange processes are simpler than in a broader system such as Macao. The concentrated emergy and currency flows in this narrow realm usually creates a lower emergy $/ \$$ ratio (e.g., for Macao, $1.42 \times 10^{12} \mathrm{sej} / \$$ ) than that of a city or region (e.g., for Macao, $2.38 \times 10^{12} \mathrm{sej} / \$$ ).

Some foods and related materials that support the gambling sector were imported from mainland China, and their emergy has been undervalued in our calculations when we adopted the lower emergy/\$ ratio of Macao $\left(2.38 \times 10^{12} \mathrm{sej} / \$\right)$ instead of using a different ratio for resources imported from China $\left(2.89 \times 10^{12} \mathrm{sej} /\right.$ $\$$; Lei et al., 2008), leading to some errors in our estimates. This problem must be solved in future research.

\section{Acknowledgements}

This research was financially supported by the National Natural Science Foundation of China (70873121; 70573106), the Knowledge Innovation Project of the Chinese Academy of Sciences (KZCX2-YW-324) and the Key Supporting Project of Ministry of Science and Technology of China (2007BAC28B04). This work was also supported by the State Key Laboratory of Subtropical Building Science of China (2008ZA09) and the Department of Guangzhou Environmental Protection Bureau (200803).

\section{References}

Abel, T., 2000. Ecosystems, sociocultural systems, and ecological-economics for understanding development: the case of tourism on the Bonaire, N.A. PhD Dissertation, University of Florida, Gainesville, Florida.

Brown, M.T., Ulgiati, S., 1999. Emergy evaluation of the biosphere and natural capital. Ambio 28, 486-493.

Brown, M.T., Ulgiati, S., 2001. Emergy measures of carrying capacity to evaluate economic investments. Population and Environment 22 (5), 471-501.

Campbell, D.E., Brandt-Williams, S.L., Cai, T.T., 2004. Current technical problems in emergy analysis. In: Brown, M.T., Campbell, D., Comar, V., Huang, S.L., Rydberg, T., Tilley, D.R., Ulgiati, S. (Eds.), Emergy Synthesis, vol. 3. The Center for Environmental Policy, Gainesville, FL, pp. 143-157.

Costanza, R., d'Arge, R., de Groot, R., Farber, S., Grasso, M., Hannon, B., Naeem, S., Limburg, K., Paruelo, J., O’Neill, R.V., Raskin, R., Sutton, P., van de Belt, M., 1997. The value of the world's ecosystem services and natural capital. Nature 387, 253-260.

Huang, S.L., 1998. Urban ecosystems, energetic hierarchies, and ecological economics of Taipei metropolis. Journal of Environment Management 52, 39-51.

Huang, S.L, Hsu, W.L., 2003. Materials flow analysis and emergy evaluation of Taipei's urban construction. Landscape and Urban Planning 63 (2), 61-74.

Hu, D., Wang, R., Lei, K.P., Li, F., Wang, Z., Wang, B.N., 2009. Expanding ecological appropriation approach: solar space method and a case study in Yangzhou city, East China. Ecological Complexity 6, 471-481.

Lan, S.F., Qing, P., Lu, H.F., 2002. The Emergy Analysis of Ecological Economy System. Chemical Industry Publishers, Beijing, pp. 1-423 (in Chinese).

Lei, K.P., Chen, F.P., Wang, Z.S., 2006. The emergy synthesis and sustainability analysis of city's environment and economy. Acta Ecologica Sinica 26 (2), 439-448 (in Chinese).

Lei, K.P., Wang, Z.S., 2008a. Emergy synthesis of tourism-based urban ecosystem. Journal of Environmental Management 88 (4), 831-844.

Lei, K.P., Wang, Z.S., 2008b. Municipal wastes and their solar transformities: emergy synthesis for Macao. Waste Management 28 (12), 2522-2531.

Lei, K.P., Wang, Z.S., Tong, S.S., 2008. Holistic emergy analysis of Macao. Ecological Engineering 32 (1), 32-33.

Li, D., Wang, R., 2009. Hybrid emergy-LCA (HEML) based metabolic evaluation of urban residential areas: the case of Beijing, China. Ecological Complexity 6, 482-491.

McCartney, G., 2005. Casinos as a tourism redevelopment strategy - the case of Macao. Journal of Macau Gaming Research Association 2, 40-48.

Odum, H.T., 1988. Energy, environment and public policy. A guide to the analysis of systems. United Nations Environmental Programme, Regional Seas Reports and Studies No. 95, Washington, DC, 109 pp.

Odum, H.T., 1996. Environmental Accounting: Emergy and Decision Making. Wiley, New York, pp. 53-219.

Odum, H.T., Odum, E.C., 2001. A Prosperous Way Down: Principles and Policies. University Press of Colorado, Niwot, Colorado, pp. 62-87.

The Gaming Inspection and Coordination Bureau of Macao, 2006. Available from: http://www.dicj.gov.mo/EN/index.htm.

The Maritime Administration, 2005. The port of Macao. Tipografia Seng Si Lda., Macao, pp.12-29.

The Statistics and Census Service, 2005. Yearbook of Statistics 2004. Macao Special Administrative Region. Government Printing Bureau, Macao, pp. 20-253. Available from: http://www.dsec.gov.mo .

Ulgiati, S., Brown, M.T., 1998. Monitoring patterns of sustainability in natural and man-made ecosystems. Ecological Modelling 108, 34-35.

Ulgiati, S., Brown, M.T., 2009. Emergy and ecosystem complexity. Communications in Nonlinear Science and Numerical Simulation 14, 310-321.

Ulgiati, S., Odum, H.T., Bastianoni, S., 1994. Emergy use, environmental loading and sustainability: an emergy synthesis of Italy. Ecological Modelling 73, 215268. 